\title{
Emerging roles of growth differentiation factor-15 in brain disorders (Review)
}

\author{
WEI-WEI JIANG ${ }^{1 *}$, ZI-ZHEN ZHANG ${ }^{2 *}$, PING-PING HE ${ }^{3,4^{*}}$, LI-PING JIANG ${ }^{1,5}$, JIN-ZHI CHEN $^{1}$, \\ XING-TING ZHANG ${ }^{1}$, MI HU ${ }^{1}$, YANG-KAI ZHANG ${ }^{1}$ and XIN-PING OUYANG ${ }^{1,4^{*}}$
}

\begin{abstract}
${ }^{1}$ Department of Physiology, Institute of Neuroscience Research, Hengyang Key Laboratory of Neurodegeneration and Cognitive Impairment, Hengyang Medical College, University of South China; ${ }^{2}$ Department of Medical Humanities, School of Medicine, Hunan Polytechnic of Environment and Biology; ${ }^{3}$ Hunan Province Cooperative Innovation Centre for Molecular Target New Drug Study, Nursing School, University of South China; ${ }^{4}$ Institute of Cardiovascular Research, Key Laboratory for Atherosclerology of Hunan Province, Hunan Province Cooperative Innovation Center for Molecular Target New Drug Study, University of South China, Hengyang, Hunan 421001; ${ }^{5}$ Department of Critical Care Medicine, Hunan Taihe Hospital, Changsha, Hunan 410004, P.R. China
\end{abstract}

Received March 5, 2021; Accepted August 6, 2021

DOI: $10.3892 / \mathrm{etm} .2021 .10705$

\begin{abstract}
Brain disorders, such as Alzheimer's and Parkinson's disease and cerebral stroke, are an important contributor to mortality and disability worldwide, where their pathogenesis is currently a topic of intense research. The mechanisms underlying the development of brain disorders are complex and vary widely, including aberrant protein aggregation, ischemic cell necrosis and neuronal dysfunction. Previous studies have found that the expression and function of growth differentiation factor-15 (GDF15) is closely associated with the incidence of brain disorders. GDF15 is a member of the TGF $\beta$ superfamily, which is a dimer-structured stress-response
\end{abstract}

Correspondence to: Dr Xin-Ping Ouyang, Department of Physiology, Institute of Neuroscience Research, Hengyang Key Laboratory of Neurodegeneration and Cognitive Impairment, Hengyang Medical College, University of South China, 28 Changsheng West Road, Hengyang, Hunan 421001, P.R. China E-mail: y1655@163.com

*Contributed equally

Abbreviations: GDF15, growth differentiation factor-15; GFRAL, GDNF receptor $\alpha$-like; AD, Alzheimer's disease; PD, Parkinson's disease; EGR-1, early growth response-1; lncRNAs, long non-coding RNAs; OSCC, oral squamous cell carcinoma; HCC, hepatocellular carcinoma; miRNAs, microRNAs; $\mathrm{CCN} 2$, connective tissue growth factor; MSA, methylseleninic acid; ARRB1, $\beta$-arrestin1; LPS, lipopolysaccharide; HRV, human rhinovirus; TGF $\beta$ RII, TGF $\beta$ receptor type II; $A \beta$, amyloid $\beta ; 6-O H D A$, neurotoxin 6-hydroxydopamine; hUCB-MSCs, human umbilical cord blood-derived mesenchymal stem cells

Key words: growth differentiation factor-15, brain disorders, Alzheimer's disease, cerebral stroke, Parkinson's disease protein. The expression of GDF15 is regulated by a number of proteins upstream, including p53, early growth response-1, non-coding RNAs and hormones. In particular, GDF15 has been reported to serve an important role in regulating angiogenesis, apoptosis, lipid metabolism and inflammation. For example, GDF15 can promote angiogenesis by promoting the proliferation of human umbilical vein endothelial cells, apoptosis of prostate cancer cells and fat metabolism in fasted mice, and GDF15 can decrease the inflammatory response of lipopolysaccharide-treated mice. The present article reviews the structure and biosynthesis of GDF15, in addition to the possible roles of GDF15 in Alzheimer's disease, cerebral stroke and Parkinson's disease. The purpose of the present review is to summarize the mechanism underlying the role of GDF15 in various brain disorders, which hopes to provide evidence and guide the prevention and treatment of these debilitating conditions.

\section{Contents}

1. Introduction

2. Structure and biosynthesis of GDF15

3. Regulation of GDF15 expression

4. Biological functions of GDF15

5. Role of GDF15 in major brain disorders

6. Conclusion and future directions

\section{Introduction}

Brain disorders, along with malignant tumors and cardiovascular disorders, are among the leading causes of morbidity and mortality worldwide (1). Brain disorders pose a serious socioeconomic burden, where the Global Burden of Disease 2017 data demonstrated that 324.4 million individuals were affected by brain disorders in Europe, which accounts for 
$79.1 \%$ of all non-communicable diseases in 2017 (1). Although cholinesterase inhibitors and dopamine-like drugs have shown considerable efficacy for the treatment of brain disorders, particularly in patients with degenerative diseases in the central nervous system, side effects and long-term sequelae remain (2). Therefore, a more detailed understanding in the mechanism underlying the progression and pathophysiology of brain disorders is crucial for developing new therapeutic strategies.

Growth differentiation factor-15 (GDF15), which was first identified in the human cDNA library that was enriched for genes associated with macrophage activation using the subtraction cloning approach, is a distant member of the TGF $\beta$ superfamily (3). GDF15 is highly expressed in the heart, liver, kidney, intestine, lung, placenta and the prostate gland (4-6). In humans, the physiological concentration of GDF15 lies in the range of $200-1,200 \mathrm{pg} / \mathrm{ml}$, where its levels increase with age (7). It has been reported that GDF15 participates in tissue repair by exerting antiapoptotic and anti-inflammatory effects whilst maintaining vascular endothelial functions $(8,9)$. There is also accumulating evidence that GDF15 is involved in the occurrence and development of cardiovascular diseases, diabetes and cancer (10-12). In 2017, research successively identified glial cell-derived neurotrophic factor receptor $\alpha$-like (GFRAL) as the receptor of GDF15 (13-16). Discovery of the GDF15/GFRAL signaling pathway provided a potentially novel target for the treatment of obesity and metabolic diseases (16-18). In recent years, accumulating evidence has also indicated that GDF15 is associated with a range of brain disorders, including Alzheimer's disease (AD), cerebral stroke and Parkinson's disease (PD) (19-21). Therefore, the aim of the present review is to summarize the regulatory processes and physiological functions of GDF15, with an emphasis on its role in brain disorders.

\section{Structure and biosynthesis of GDF15}

The GDF15 gene can be mapped onto the chromosome 19p13.1-13.2 genomic locus, which contains two exons and one single intron with an open reading frame of $924 \mathrm{bp}(3)$. Its corresponding mRNA can be translated into a 308-amino acid polypeptide, which is composed of the following three parts: Signal peptide, pro-peptide region and a mature region on the carboxyl terminus (3). The mature domain of 112 amino acids is first separated from the propeptide region of 167 amino acids by a furin-like convertase, which is then cleaved by furin/paired basic amino-acid-cleaving enzyme 4 and MMP-26 $(22,23)$. The mature domain of GDF15 contains a highly conserved pattern of seven cysteine residues, where six of these form intra-chain disulfide bonds, forming a highly stable cysteine structure that is resistant to physical and chemical damage, including enzymatic attacks (24). Unlike other TGF $\beta$ families of proteins, the propeptide is not required for proper GDF15 folding (25). Although propeptides may facilitate the detection of improper GDF15 folding, engineered GDF15 that lacks the pro-peptide domain can still be secreted in its proper folded form (26). GDF15 is generally secreted as a dimer that is formed by inter-chain disulphide bonds, which performs complex biological functions through autocrine or paracrine pathways (Fig. 1) (25). In addition, GDF15 can be secreted as an unprocessed pro-peptide, where it can bind to the extracellular matrix (ECM) through its 89 amino acids on the $\mathrm{C}$-terminal domain in a reversible manner in prostate cancer (27). There, GDF15 can be released from the ECM into the circulation by locally acting MMPs or pro-convertases (27).

\section{Regulation of GDF15 expression}

GDF15 is a type of stress-response protein (28). It was previously reported that GDF15 expression is markedly increased under conditions of inflammation, ischemia, hypoxia and organ damage (29). GDF15 is important for the regulation of angiogenesis, apoptosis, lipid metabolism and inflammation, some of the factors that have been found to regulate GDF15 expression are discussed in this section.

p53. As a tumor suppressor gene, p53 serves a key role in controlling cell proliferation, inhibiting malignant cell proliferation and regulating cell cycle progression (30). p53 was one of the first transcription factors that was identified to be transcriptional regulators of GDF15 expression (31). There are $\geq$ two 553 binding sites in the GDF15 promoter, one near the transcription start site and another in the region that lie 851 bp upstream of the transcription start site (31), where both binding sites can transactivate the GDF15 promoter (31). It was previously reported that GDF15 expression was robustly upregulated following the overexpression or pharmacological induction of p53 in human lung cancer cell lines, osteosarcoma cell lines and breast cancer cell lines $(32,33)$. In addition, the DNA intercalator doxorubicin was found to significantly increase GDF15 expression in p53 wild-type human breast cancer cell lines, but exerted no effects on p53-null cells (34). In vitro, GDF15 expression was found to be markedly increased in human bronchial epithelial cells and human pulmonary vascular endothelial cells upon exposure to hyperoxia, whilst p53 knockdown robustly reduced this induction of GDF15 transcription by hyperoxia (35). Therefore, this suggests that p53 is an important regulator of the production of GDF15. Similarly, C-reactive proteins in human aortic endothelial cells and human maternal expression gene 3 in colon cancer cell lines were both shown to induce GDF15 expression by recruiting the p53 protein $(36,37)$. Different members of the p53 tumor suppressor gene family have been demonstrated to exhibit different binding affinities for GDF15 (38). The GDF15 promoter region contains two p53-type response elements (RE), RE1 and RE2, where most 3' quarter-sites (areas bound by the p53 tetramer) in RE2 exhibit a higher binding affinity for $\mathrm{p} 53$ (38). Therefore, GDF15 is activated by $\mathrm{p} 53$ to a greater extent compared with that by other related family members, including p63 and p73 (38).

Early growth response-1 (EGR-1). EGR-1 is a transcription factor that contains three zinc finger domains and is considered to be an important regulator of GDF15 (39). A number of studies have previously shown that pharmacological agonists, such as troglitazone and non-steroidal anti-inflammatory drugs, can increase EGR-1 expression in human colon cancer cell lines prior to GDF15 induction, supporting the hypothesis that GDF15 is a downstream target of EGR-1 (40-42). Indeed, position -73 to -51 of the GDF15 promoter contains 
A

19p13.1-132
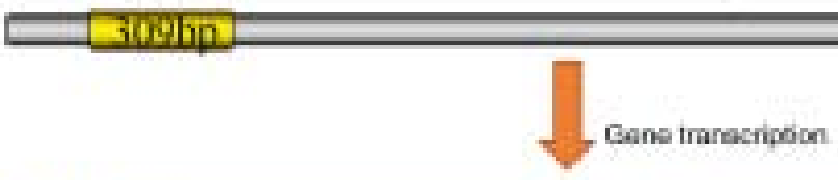

mPHA 1295 tp

\section{Tilin}
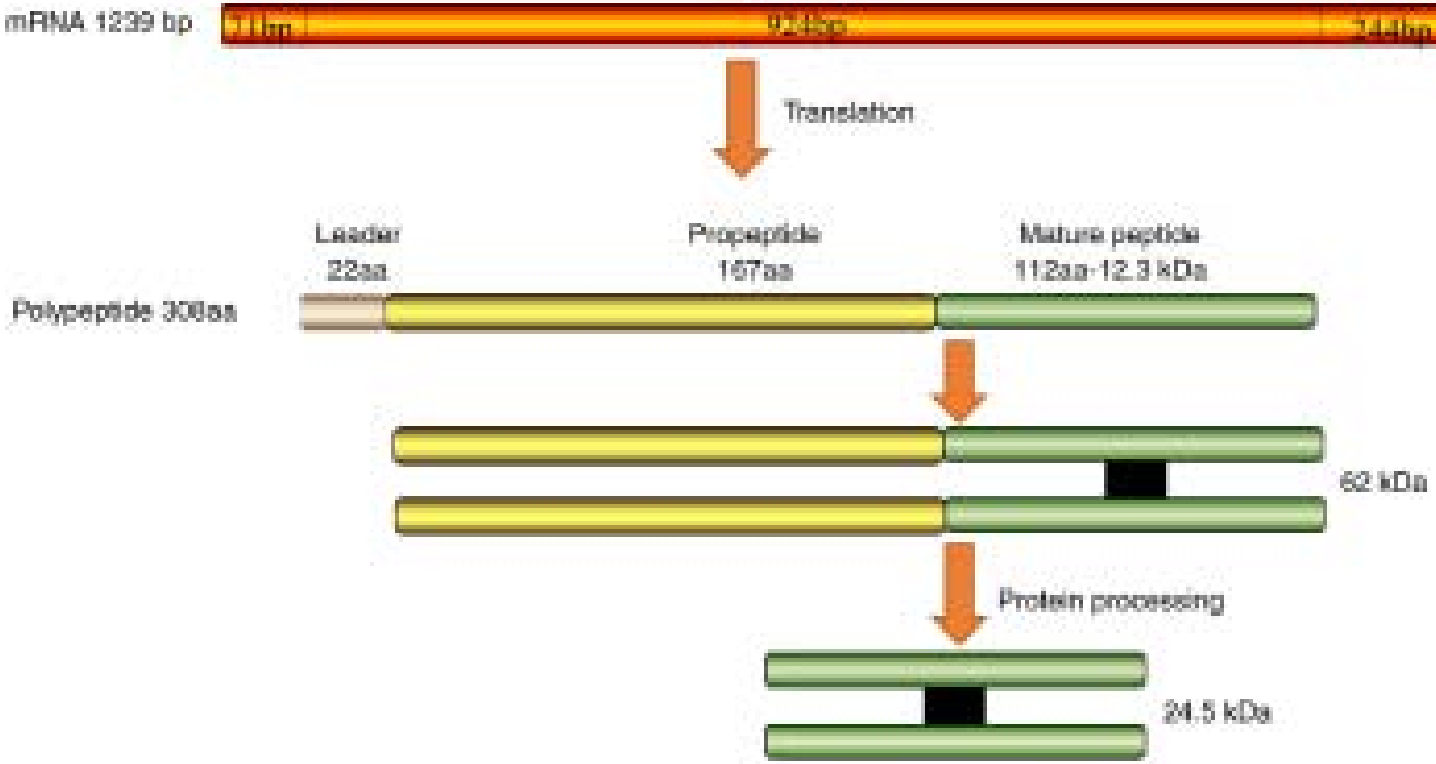

B

Endwes
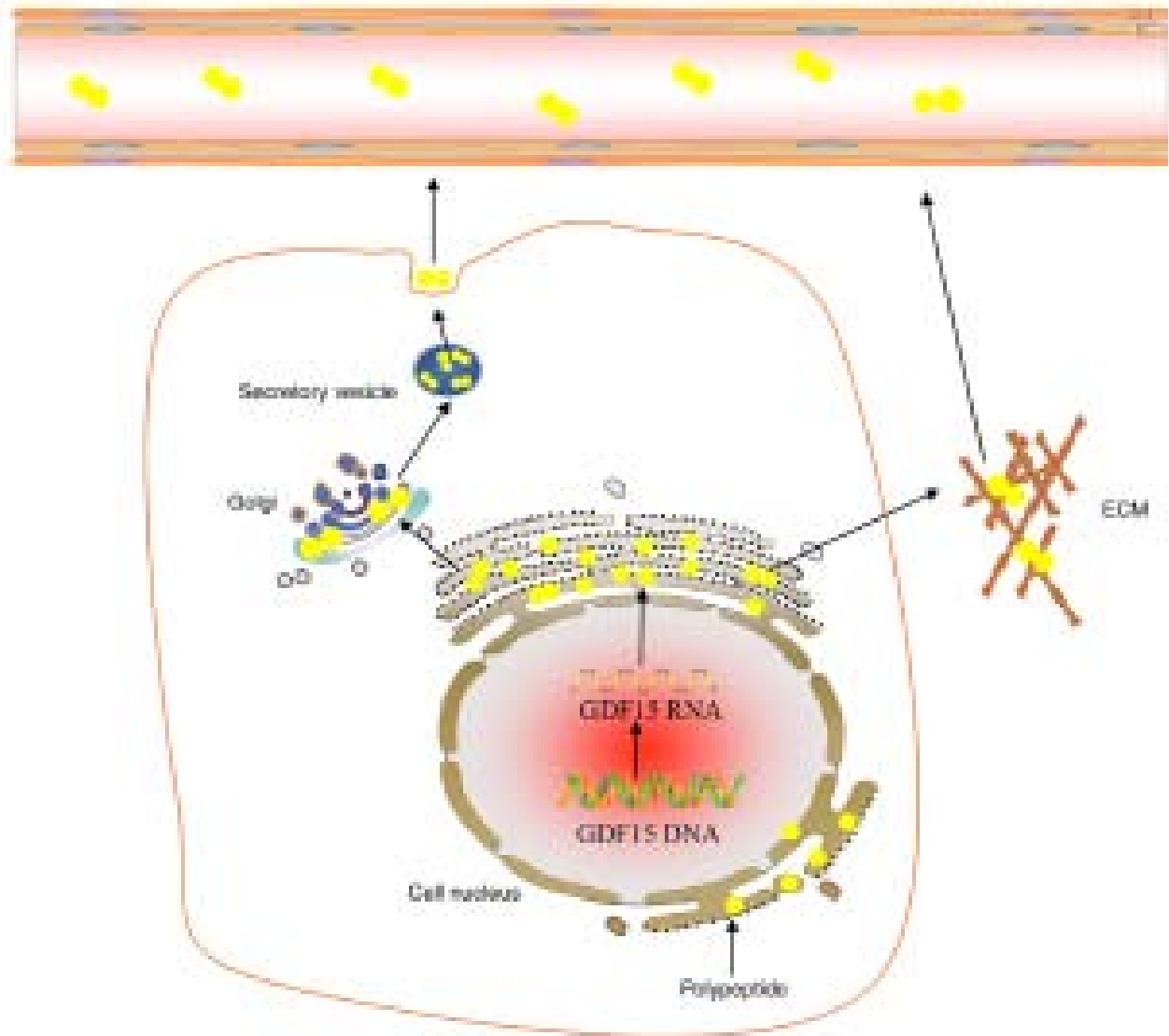

Figure 1. Synthesis and Secretion of GDF15. (A) GDF15 gene that is located on the chromosome 19p13.1-13.2 genomic locus can produce a mRNA of $1239 \mathrm{BP}$. And the mRNA is translated into a 308 amino acid polypeptide, which includes signal peptide, pro-peptide region and a mature region. Then the mature domain is separated from the propeptide region by a furin-like convertase. (B) After transcription, translation and processing, GDF15 (yellow circle) is formed into a 62-kDa protein, which is transported into the circulation through vesicles. In addition, the unprocessed GDF15 can also be directly secreted to bind to ECM. After hydrolysis by metalloenzymes or pro-convertases, GDF15 enters the circulation from ECM. GDF15, growth differentiation factor-15; ECM, extracellular matrix. 
EGR-1-binding sites (43). Furthermore, DNA methylation at the -53 site of the GDF15 promoter site blocks the binding of EGR-1, which subsequently inhibits GDF15 induction in vitro (43). By contrast, GDF15 transcription by EGR-1 can be restored following incubation with 5-aza-2'-deoxycytidine (a demethylating reagent) (43). Accordingly, in HT29 colon carcinoma cells, activity of the GDF15 promoter and GDF15 expression are markedly increased by the ectopic expression of EGR-1 in a dose-dependent manner, whereas EGR-1 knockdown using small interfering (si)RNAs was shown to significantly decrease silibinin-induced GDF15 expression (44). These observations suggest that EGR-1 is a direct transcriptional regulator of GDF15.

Long non-coding RNAs (lncRNAs) and microRNAs (miRNAs/miRs). LncRNAs represents a class of RNAs that cannot be translated into proteins and are typically $>200$ nucleotides in length (45). It has been reported extensively that IncRNAs can serve key roles in the regulation of gene expression. Kong et al (46) previously revealed that LINC0113 overexpression decreased the mRNA and protein expression levels of GDF15 in oral squamous cell carcinoma (OSCC) cell lines, whilst treatment with the exogenous recombinant human GDF15 protein was able to restore the migratory and invasive abilities of OSCC cells that was previously weakened by LINC0113. In addition, a significant positive correlation was identified between IncRNA plasmacy toma variant translocation 1 (PVT1) expression and GDF15 expression in hepatocellular carcinoma (HCC) tissues (47). GDF15 knockdown using siRNAs significantly suppressed the proliferation of HCC cells caused by lncRNA PVT1 overexpression, suggesting that lncRNA PVT1 may be an important upstream regulator of GDF15 expression in HCC cells (47). Another study also revealed that $\mathrm{CCAAT} / \mathrm{enhancer-binding}$ protein $\beta$ (CEBPB) can bind to the promoter of GDF15 to facilitate GDF15 gene expression in ovarian cancer cell lines (48). In addition, GDF15 expression was previously found to be negatively associated with that of the lncRNA growth arrest-specific 5 (GAS5) in ovarian cancer tissues (48). Mechanistically, lncRNA GAS5 was shown to competitively bind to CEBPB to inhibit the promoting effect of CEBPB on GDF15 transcription (48). It is expected that additional lncRNAs involved in the regulation of GDF15 expression will be discovered by future studies.

Similar to IncRNAs, miRNAs are also an important component of gene transcription regulators, which functions by pairing with the 3 '-untranslated region of target mRNAs (49). Both miR-873-5p and miR-1233-3p have been shown to exert suppressive effects on GDF15 expression in melanoma cell lines (50). However, single-nucleotide polymorphism in miRNA, rs1054564, was located in the GDF15'UTR complementary to the hsa-miR-1233-3p seed region, and the presence of this $\mathrm{C}$-allele was discovered to weaken the binding of hsa-miR-1233-3p to GDF15, thereby enhancing the expression of the GDF15 protein (50). miR-3189 is a primate-specific miRNA that is embedded within the introns of GDF15 (51). Increased miR-3189 expression results in elevated GDF15 expression by downregulating p53 in colorectal cancer cell lines (51). In addition, overexpression of miR-3189 in HCT116-p53\% colorectal cancer cells was shown to upregulate the expression of a subset of p53 targets, including GDF15 and growth arrest and DNA-damage-inducible $45 \alpha$ (51).

Hormones and hormone derivatives. Hormones and hormone derivatives have also been demonstrated to lie upstream of GDF15 (52). Primary adrenal insufficiency is accompanied by an increase in GDF15 expression, where glucocorticoid replacement therapy was shown to effectively reduce this concentration of GDF15 in a dose-dependent manner (53). In brown adipose tissues, noradrenergic cAMP-mediated thermogenic activation was found to increase GDF15 gene expression and subsequent release (54). In addition, metformin was reported to increase GDF15 levels, but it had no effect on GFRAL receptor-deficient mice (52). Zhao et al (55) previously found that thyroid hormone levels were independently associated with GDF15 expression, such that T3 treatment promoted GDF15 expression in brown adipose tissues of C57BL/6 mice. Furthermore, previous in vivo and vitro experiments demonstrated that testosterone and estradiol treatment reduced GDF15 secretion through androgen receptor/estrogen receptor-mediated signaling pathways (56).

\section{Biological functions of GDF15}

Angiogenesis. Accumulating evidence has suggested that GDF15 is a potential stimulator of angiogenesis (Table I). After being secreted by senescent endothelial colony-forming cells generated from adult human blood in a paracrine manner, GDF15 can promote proliferation, migration and NO production in non-senescent endothelial colony-forming cells generated from adult human blood (57). During this process, a number of signaling pathways are activated by GDF15 in an oxidative stress-independent manner, including AKT, ERK1/2 and Smad2 (57). This improved the function of vascular progenitor cells, which may serve therapeutic effects on the damaged vascular system (57). Similarly, GDF15 can also enhance the expression of cyclins D1 and E in HUVECs through the PI3K/AKT, JNK and ERK signaling pathways to promote the proliferation of endothelial cells (58). GDF15 is also involved in the mechanism underlying ischemia/reperfusion injury. During the process of cardiac ischemia, GDF15 was shown to stimulate the angiogenesis of hypoxic HUVECs by inhibiting p53 signaling whilst upregulating hypoxia-inducible factor $1 \alpha$ expression (59). Furthermore, since the repair of large bone defects remains to be a major medical challenge, GDF15 was shown to represent a potentially effective solution. Wang et al (60) found that GDF15 can promote the formation of functional blood vessels at the site of artificially-induced angiogenesis, which significantly improved the healing of critical-sized calvarial defects. Neovascularization is one of the major characteristics in cancer (61). Following chemotherapy, the expression of GDF15 was found to be markedly upregulated in HCC (62). GDF15 can induce Src and then activate AKT, MAPK and NF- $\mathrm{KB}$ downstream in $\mathrm{HCC}$, which promotes the proliferation, migration and tube formation of surrounding endothelial cells in vitro (62). By contrast, thalidomide, an agent with known anti-angiogenic activities, can significantly attenuate and reverse these effects aforementioned (62). In addition, it was found that GDF15 interacted with connective tissue growth factor (CCN)-2, to inhibit 
Table I. Biological functions of GDF15.

\begin{tabular}{|c|c|c|c|}
\hline Actions & Experimental models & Mechanisms & (Refs.) \\
\hline \multicolumn{4}{|l|}{ Angiogenesis } \\
\hline \multirow[t]{4}{*}{ Pro-angiogenesis } & $\begin{array}{l}\text { Endothelial colony forming cells } \\
\text { generated from adult human blood }\end{array}$ & $\uparrow \mathrm{NO}, \uparrow \mathrm{AKT}, \mathrm{ERK} 1 / 2$ and SMAD2 & $(57)$ \\
\hline & HUVEC & $\begin{array}{l}\uparrow \mathrm{Cyclin} \text { D1 and E, } \uparrow \text { retinoblastoma } \\
\text { phosphorylation and E2F-1 nuclear translocation }\end{array}$ & $(58)$ \\
\hline & HUVEC & $\downarrow$ p53, hypoxia-induced factor- $1 \alpha$ & $(59)$ \\
\hline & Hepatocellular carcinoma & $\uparrow$ Src and AKT, MAPK and NF- $\kappa$ B downstream & $(62)$ \\
\hline Anti-angiogenesis & HUVEC & $\downarrow$ Connective tissue growth factor $2 /$ focal adhesion kinase & $(63)$ \\
\hline \multicolumn{4}{|l|}{ Apoptosis } \\
\hline \multirow[t]{3}{*}{ Pro-apoptosis } & Prostate cancer cells & $\uparrow$ Methylseleninic acid, $\uparrow$ caspase-dependent apoptosis & $(66,67)$ \\
\hline & Activated macrophages & $\uparrow$ PARP, caspase- 3 or AIF & $(68)$ \\
\hline & A459 cells & $\begin{array}{l}\uparrow \text { caspase- } 9 \text { and caspase- } 3 \text {; } \downarrow \text { ERK } 1 / 2 \text { and p38 MAPK } \\
\text { phosphorylation }\end{array}$ & $(69)$ \\
\hline \multirow[t]{2}{*}{ Anti-apoptosis } & HUVEC & $\begin{array}{l}\uparrow \mathrm{PI} 3 \mathrm{~K} / \mathrm{AKT} / \text { endothelial nitric oxide synthase; } \\
\downarrow N F-\kappa \mathrm{B} / \mathrm{JNK}\end{array}$ & $(70)$ \\
\hline & $\begin{array}{l}\text { Patients with pulmonary } \\
\text { hypertension }\end{array}$ & $\uparrow \mathrm{AKT}$ & $(71)$ \\
\hline \multirow[t]{4}{*}{ Lipid metabolism } & Transgenic GDF15 mice & $\uparrow$ Key thermogenic and lipolytic genes & $(73)$ \\
\hline & Mice fed with high-fat diet & $\uparrow$ Glial cell-derived neurotrophic factor receptor $\alpha$-like & (74) \\
\hline & $\begin{array}{l}\text { Patients with non-alcoholic } \\
\text { steatohepatitis }\end{array}$ & $\begin{array}{l}\uparrow \beta \text {-arrestin } 1 ; \uparrow \beta \text {-oxidation genes; } \\
\downarrow \text { fatty acids }\end{array}$ & $(75)$ \\
\hline & Fasted mice & $\uparrow$ Fatty acid $\beta$-oxidation and ketogeneis & (76) \\
\hline \multicolumn{4}{|l|}{ Inflammation } \\
\hline \multirow[t]{2}{*}{ Anti-inflammation } & $\begin{array}{l}\text { Mice treated with } \\
\text { lipopolysaccharide }\end{array}$ & $\begin{array}{l}\downarrow \text { Monocyte chemoattractant protein- } 1 \text {, } \\
\text { TNF- } \alpha \text {, transforming growth factor- } \beta \text {-activated kinase } 1 \\
\text { phosphorylation and NF- } \kappa B\end{array}$ & $(79,81)$ \\
\hline & Mice & $\uparrow$ Triglyceride metabolism & $(77)$ \\
\hline \multirow[t]{2}{*}{ Pro-inflammation } & Human GDF15 transgenic mice & $\downarrow$ IFN- $\lambda 2 / 3$ mRNA & $(78)$ \\
\hline & $\begin{array}{l}\text { Human transgenic mice tracheal } \\
\text { epithelial cells }\end{array}$ & $\downarrow$ IFN- $\lambda 1 /$ IL-29 & (78) \\
\hline
\end{tabular}

$\uparrow$, enhancement or promotion; $\downarrow$, reduction or inhibition; GDF-15, growth differentiation factor-15; HUVECs, human umbilical cord vascular endothelial cells; IFN, interferon.

CCN2-mediated focal adhesion kinase activation, which in turn decreased av $\beta 3$ integrin clustering in HUVECs, to exert antagonistic effects on angiogenesis (63). This phenomenon is conducive to understanding the role of GDF15 under various disease conditions further.

Cell apoptosis. Apoptosis is a process in which cell death occurs in an orderly manner and is crucial for the maintenance of internal homeostasis (64). Owing to its reported function as a stress-response protein, GDF15 has been reported to regulate apoptosis (65). GDF15 is a downstream target of methylseleninic acid (MSA), where GDF15 knockdown significantly inhibited the apoptosis of prostate cancer cells mediated by MSA $(66,67)$. By contrast, GDF15 overexpression made prostate cancer cells flattened and more spread out and induced caspase-dependent apoptosis $(66,67)$. GDF-15 was inducible in human macrophages by oxidized low density lipoprotein and its mediators in vitro, and GDF15 immunoreactivity was colocalized with apoptosis markers such as PARP, caspase-3 or apoptosis-inducing factor immunoreactivity, suggesting that GDF15 may modulate apoptosis process in activated macrophages (68). In addition, A549 lung adenocarcinoma cell apoptosis was also induced by GDF15 overexpression through promoting caspase-9 and caspase-3 expression and inhibition of ERK1/2 and p38 activation, which was mediated in a TGF $\beta$ receptor type II (TGF $\beta$ RII)-dependent manner (69). Conversely, GDF15 can exert a protective effect against the apoptosis of HUVECs induced by high glucose concentrations (70). Mechanistically, this effect may be caused by GDF15 maintaining the activity of PI3K/Akt/eNOS pathway and attenuating NF- $\kappa \mathrm{B} / \mathrm{JNK}$ pathway (70). In addition, under conditions of hypoxia and laminar shear stress, GDF15 expression in the pulmonary microvascular endothelial cells of patients with pulmonary arterial hypertension was found to be significantly higher compared with that in normal lung tissues, where the extent 
of cell apoptosis was reduced by GDF15 overexpression in an AKT-dependent manner (71).

Lipid metabolism. GDF15 can serve as a potential lipid metabolism regulator (72). GDF15 overexpression conferred higher resistance to diet- and genetic-induced obesity in transgenic GDF15 mice compared with that in wild-type mice by increasing lipid oxidation whilst promoting the expression of thermogenic genes and adipose tissue metabolism (73). Following treatment with the GDF15 antibody, the weight, obesity and the degree of liver lipid deposition of mice fed on a high-fat diet were markedly higher compared with those in the control group (74). Therefore, GDF15 may be a potential target for the treatment of fatty liver disease. Zhang et al (75) revealed that $\beta$-arrestin 1 (ARRB1) deficiency in patients with non-alcoholic steatohepatitis was accompanied with increased free fatty acid levels and decreased $\beta$-oxidation gene expression in a GDF15-dependent manner in liver. In addition, ARRB1 was found to interact with GDF15 to promote the translocation of the GDF15 precursor to the Golgi body for cleavage and maturation (75). During fasting, the inositol-requiring enzyme $1 \alpha / \mathrm{X}$-box binding protein axis can increase the expression of GDF15 by binding to its promoter to promote fatty acid oxidation and ketone production in the liver (76). However, GDF15 knockout can significantly suppress $\beta$-oxidation and ketogenesis in mice with streptozocin-induced type I diabetes or in mice subjected to fasting (76).

Inflammatory response. In addition to the aforementioned functions, GDF15 can also exert anti-inflammatory and proinflammatory properties $(77,78)$. GDF15 can inhibit the inflammatory response induced by lipopolysaccharide (LPS) (79). A previous study demonstrated that GDF15-knockout mice displayed worsened characteristics following the induction of LPS-induced renal and cardiac injury, whilst GDF15 overexpression conferred opposite effects (80). GDF15 can inhibit the activation of the NF- $\kappa B$ pathway to reduce the production of proinflammatory factors, including moncocyte chemoattractant protein-1 and TNF- $\alpha$ (81). This in effect prevents LPS-induced liver injury in mice by blocking the phosphorylation of TGF $\beta$-activated kinase 1 (81). Luan et al (77) previously reported that GDF15 improved cardiac and hepatic tolerance to inflammation in mice by regulating triglyceride metabolism. GDF15 was also found to regulate the response to in human rhinovirus (HRV) infection and virus-induced lung inflammation (78). In human GDF15 transgenic mice, the overexpression of GDF15 resulted in enhanced inflammatory responses to HRV and decreased IFN- $\lambda 2 / 3$ mRNA expression (78). In addition, the IFN- $\lambda 1 /$ IL-29 protein, which has antiviral activity, was found to be inhibited by GDF15 in tracheal epithelial cells from human GDF15 transgenic mice, which promoted HRV replication and the subsequent inflammatory response (78).

\section{Role of GDF15 in major brain disorders}

$A D . \mathrm{AD}$ is a progressive neurodegenerative disease that mainly manifests with clinical symptoms of cognitive and behavioral impairment (82). The pathogenesis of $\mathrm{AD}$ is complex and may involves amyloid $\beta(\mathrm{A} \beta)$ accumulation, tau protein toxicity, synaptic damage, mitochondrial dysfunction and oxidative stress (83). GDF15 expression can be detected in the adult rat central and peripheral nervous systems, where it is mainly secreted into the cerebrospinal fluid $(84,85)$. It has been demonstrated that GDF15 is closely associated with cognitive impairment, which is a major characteristic of $\mathrm{AD}$ (86). It was also previously shown that cognitive impairments due to dementia and AD were associated with higher GDF15 levels, particularly in the presence of cerebrovascular disease (87). By contrast, GDF15-deficient mice were shown to exhibit superior fear-associated memory and sensorimotor gating, which is conducive to cognition (88). Decreased numbers of white matter and grey matter nerve fibers, coupled with the increased volume of atrophy, may be important pathophysiological features of AD (89). Jiang et al $(90,91)$ revealed that higher GDF15 levels were negatively correlated with gray matter volume and white matter integrity. In addition, GDF15 expression likely exhibits a close association with learning and memory impairments, where the hippocampus is the region that is typically worst affected by AD (86,92). GDF15-knockout mice were shown to display a progressive loss of motor neurons coupled with the decreased proliferation and migration of adult hippocampal progenitor cells $(93,94)$. This appears to be a result of the absence of epidermal growth factor receptor signaling stimulation, which is normally promoted by GDF15 in a CXC chemokine receptor 4-dependent manner $(93,94)$. Kim et al $(95)$ reported that human recombinant GDF15 can enhance the proliferation and synaptic activity of mouse hippocampal neural stem cells both in vitro and in vivo, whereas GDF15 knockdown can reduce the proliferation of hippocampal neural stem cells in vitro. Within the neural network, the synapse forms a key component in mediating signal transmission between neurons, which underlies the mechanism of the generation and retention of memories (96). It was previously reported that GDF15 promoted synaptic glutamate release and increased the miniature excitatory post-synaptic current frequency in the medial prefrontal cortex of mice (97). The potential mechanism was mediated through activation of TGF $\beta$ RII-mediated ERK1/2 signaling to promote $\mathrm{Ca}_{\mathrm{v}} 3.1$ and $\mathrm{Ca}_{\mathrm{v}} 3.3 \alpha$ subunit expression, which increases T-type calcium channel activity (97). This suggests that GDF15 deficiency may impact synaptic function and accelerate $\mathrm{AD}$ progression (97). The production and accumulation of $A \beta$ is one of the main mechanisms underlying AD development (98). TGF $\beta$ RII is mainly expressed in the microglia and neurons, where it participates in GDF15-associated signaling pathways including Akt/mTOR pathway. GDF15 as a soluble paracrine factor can act on microglial cells to increase the expression level of TGF $\beta$ RII during AD (12). In addition, GDF15 can enhance the activity of insulin-degrading enzyme which, together with TGF $\beta$ RII, can promote $A \beta$ protein clearance (12). Decreased expression levels of TGF $\beta$ RII were found in human and mouse models of $\mathrm{AD}$, which may be the underlying cause of the increased $A \beta$ accumulation and neurodegeneration (Fig. 2) $(99,100)$. In summary, GDF15 appears to be involved in AD not only by promoting hippocampal neurogenesis and synaptic activity, but also by enhancing the clearance of the $\mathrm{A} \beta$ protein. Therefore, GDF15 may represent an attractive therapeutic target for $\mathrm{AD}$. 


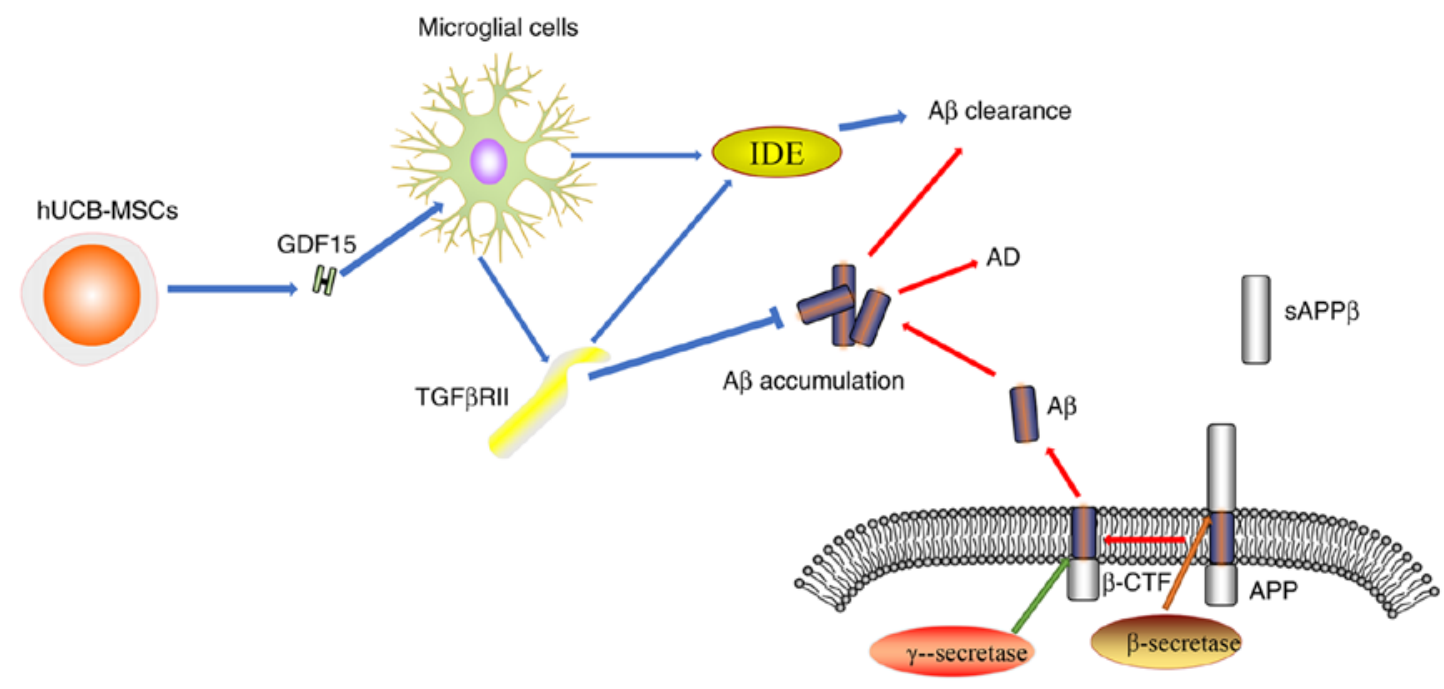

Figure 2. Association between GDF15 and AD. APP protein is hydrolyzed by $\beta$-secretase. SAPP $\beta$ is released into the extracellular matrix and $\beta$-CTF and $A \beta$ are produced by $\gamma$-Secretase. A $\beta$ accumulation is a leading cause of AD. hUCB-MSCs secrete GDF15, which can increase the expression of TGF $\beta R I I$ on microglia through a paracrine mechanism, TGF $\beta$ RII in turn exerts a protective effect by inhibiting $A \beta$ accumulation. TGF $\beta$ RII can also increase the expression of IDE induced by GDF15. IDE is a degradation enzyme that can promote the clearance of A $\beta$. GDF15, growth differentiation factor-15; AD, Alzheimer's disease; A $\beta$, amyloid $\beta$; hUCB-MSCs, human umbilical cord blood-derived mesenchymal stem cells; TGF $\beta$ RII, TGF $\beta$ receptor type II; IDE, insulin-degrading enzyme; SAPP $\beta$, soluble peptide APP $\beta$; APP, amyloid precursor protein; $\beta$-CTF, $\beta$-secretase-derived fragment, C99.

Cerebral stroke. Cerebral stroke is an acute cerebrovascular disease, the pathogenesis of which is characterized by inadequate blood flow to the brain due to the rupture or occlusion of cerebrovascular vessels, thereby causing brain damage (101). Stroke can be divided into two categories, namely ischemic and hemorrhagic stroke, where American Stroke Association data in 2018 indicated that ischemic stroke accounted for $87 \%$ of all cases (102). Since GDF15 levels were found to be elevated after tissue injury, ischemia or hypoxia, it was hypothesized that there may be an association between GDF15 and stroke. Xiang et al (103) demonstrated that the genotype and allele frequencies of the GDF15 rs1804826G/T polymorphism were associated with the risk of cerebral stroke within the Chinese population. In a prospective, nested, case-controlled study of 27,628 initially healthy female individuals, Brown et al (104) revealed that the GDF15 concentration in patients with cardiovascular events, including stroke, was higher compared with that in individuals without cardiovascular events. In addition, a concentration higher than the 90th percentile $(>856 \mathrm{pg} / \mathrm{ml})$ was associated with a 2.7 -fold increase in the risk of developing cardiovascular events (104). Previous studies reported that GDF15 levels may serve as a prognostic marker in patients with a history of stroke $(105,106)$. Several lines of evidence also revealed that the level of GDF15 was found to be positively associated with the severity of ischemic stroke, such that GDF15 can be used as a biomarker for predicting an unfavorable outcome 90 days after the stroke event $(107,108)$. Plasma GDF15 concentration on admission has been reported to serve as an independent prognostic biomarker of mortality in patients with ischemic stroke following acute revascularization therapy (17). A previous study also investigated the relationship between GDF15 and in 254 patients with hypertension who suffered from stroke for the first, which found that GDF15 can be used as an independent predictor of stroke in individuals without any prior history of stroke (109). In addition, it was reported that GDF15 mRNA expression was markedly upregulated in the hippocampus and parietal cortex of mice at 3 and $24 \mathrm{~h}$ after middle cerebral artery occlusion (110). This suggests that GDF15 can participate in the regulation of post-lesion responses, further supporting the notion that GDF15 participates in the occurrence and development of cerebral stroke (110).

$P D$. The main property of PD is the degeneration and loss of dopaminergic neurons in the substantia nigra and nigrostriatal pathway, which is caused by the formation of Lewy bodies as a result of aberrant $\alpha$-synuclein deposition (111). PD is characterized by symptoms of dyskinesia, including tremor, stiffness, slow motion and unstable posture (111). PD also has a complex and multifactorial pathological process, which typically involves the aggregation of $\alpha$-synuclein, oxidative stress, mitochondrial dysfunction, iron deposition and neuronal apoptosis (112). Maetzler et al (113) previously revealed that GDF15 exhibited a positive correlation with the age of PD symptom onset, Hoehn and Yahr scale score and expression of the neurodegenerative marker Tau. GDF15 was also identified to be an independent risk factor for Unified Parkinson's Disease Rating Scale-III score through multiple linear regression analysis, where subsequent receiver operating characteristic curve analysis revealed that GDF15 exhibited a sensitivity of $71.15 \%$ and a specificity of $87.50 \%$ for the detection of PD (114,115). However, since GDF15 levels exhibit substantial overlap between patients with PD and healthy individuals, this marker alone may not be sufficient as a diagnostic tool. However, these aforementioned findings indicate collectively that GDF15 expression is closely associated with PD.

The neurotoxin 6-hydroxydopamine (6-OHDA) can be taken up preferentially by dopaminergic and noradrenergic transporters, leading to the degeneration of catecholaminergic neurons (116). Strelau et al (84) demonstrated that unilateral injections of GDF15 into the medial forebrain bundle immediately above the substantia nigra prior to 6-OHDA 
administration were able to confer protection against complete lesion formation induced by 6-OHDA, which prevented the loss of the dopaminergic neurons. Consistently, Machado et al $(117,118)$ further demonstrated that endogenous GDF15 may promote the survival of dopaminergic neurons by regulating the inflammatory response after 6-OHDA-induced brain injury. GDF15 released by astrocytes exerted a protective effect on vulnerable nigral neurons during PD and on induced pluripotent stem cell-derived dopaminergic neurons subjected to 1-methyl-4-phenylpyridinium toxicity, which may explain the selective degeneration or protection of dopaminergic neurons in PD because GDF15 is expressed 230-fold higher in the neighboring ventral tegmental area astrocytes than the substantia nigra pars compacta $(20,119)$. Mitochondrial dysfunction is another possible mechanism that has been proposed to serve a role in PD (112). The HT22 hippocampal cell line is considered to be a suitable model for studying PD. GDF15 overexpression was shown to reverse the effects of oxygen consumption, cell viability and mitochondrial membrane potential caused by oligomycin in HT22 cells, where further study revealed that GDF15 may regulate mitochondrial membrane potential and oxygen consumption through the PI3K/AKT signaling pathway (120). Furthermore, GDF15 was reported to be a more sensitive measure for diagnosing mitochondrial dysfunction compared with that of lactate stress test in Japanese patients with PD (121). Collectively, these findings suggest that GDF15 may promote the survival of dopaminergic neurons and exerts a protective effect by preserving normal mitochondrial function.

\section{Conclusion and future directions}

GDF15 is widely expressed in brain tissues and has been found to be involved in the pathophysiological processes underlying a number of brain disorders, particularly in $\mathrm{AD}$, cerebral stroke and PD. Although progress has been made over the past decade, several unresolved problems remain. The specific signaling pathways mediated by GDF15 in AD have not been fully elucidated. In addition, the reference range and sensitivity of GDF15 as a biomarker for the prognosis and risk stratification of related diseases have yet to be determined. Furthermore, it remains unknown if there are other GDF15 receptors involved in mediating the pathophysiological processes of brain disorders in addition to the GFRAL receptor. Whether the plasma concentration of GDF15 can be artificially regulated to treat brain disorders is also a question that require further study. Therefore, addressing these questions aforementioned may provide further clues for the prevention and treatment of these brain disorders.

\section{Acknowledgements}

Not applicable.

\section{Funding}

The authors acknowledge the financial supports from the Natural Science Foundation of Hunan Province, (grant nos. 2019JJ40249 and 2018JJ3455), Outstanding Young Aid Program for Education Department of Human Province (grant no. 18B274), the Major Project of Social Science
Achievement Review Committee in Hunan Province (grant no. XSP20ZDI013), Key Project of Hunan Provincial Department of Education (grant no. 20A427).

\section{Availability of data and materials}

Not applicable.

\section{Authors' contributions}

WWJ, ZZZ, PPH, XPO contributed to data gathering, manuscript drafting, critical revision of the manuscript. LPJ, JZC, XTZ, MH and YKZ revised the manuscript. All authors read and approved the final manuscript. Data authentication is not applicable.

\section{Ethics approval and consent to participate}

Not applicable.

\section{Patient consent for publication}

Not applicable.

\section{Competing interests}

The authors declare that they have no competing interests.

\section{References}

1. Raggi A and Leonardi M: Burden of brain disorders in Europe in 2017 and comparison with other non-communicable disease groups. J Neurol Neurosurg Psychiatry 91: 104-105, 2020.

2. Bautista-Aguilera OM, Ismaili L, Iriepa I, Diez-Iriepa D, Chabchoub F, Marco-Contelles J and Pérez M: Tacrines as therapeutic agents for alzheimer's disease. V. recent developments. Chem Rec 21: 162-174, 2021.

3. Bootcov MR, Bauskin AR, Valenzuela SM, Moore AG, Bansal M, He XY, Zhang HP, Donnellan M, Mahler S, Pryor K, et al: MIC-1, a novel macrophage inhibitory cytokine, is a divergent member of the TGF-beta superfamily. Proc Natl Acad Sci USA 94: 11514-11519, 1997.

4. Yokoyama-Kobayashi M, Saeki M, Sekine S and Kato S: Human cDNA encoding a novel TGF-beta superfamily protein highly expressed in placenta. J Biochem 122: 622-626, 1997.

5. Bottner M, Laaff M, Schechinger B, Rappold G, Unsicker K and Suter-Crazzolara C: Characterization of the rat, mouse, and human genes of growth/differentiation factor-15/macrophage inhibiting cytokine-1 (GDF-15/MIC-1). Gene 237: 105-111, 1999.

6. Koopmann J, Buckhaults P, Brown DA, Zahurak ML, Sato N, Fukushima N, Sokoll LJ, Chan DW, Yeo CJ, Hruban RH, et al: Serum macrophage inhibitory cytokine 1 as a marker of pancreatic and other periampullary cancers. Clin Cancer Res 10: 2386-2392, 2004.

7. Wiklund FE, Bennet AM, Magnusson PK, Eriksson UK, Lindmark F, Wu L, Yaghoutyfam N, Marquis CP, Stattin P, Pedersen NL, et al: Macrophage inhibitory cytokine-1 (MIC-1/GDF15): A new marker of all-cause mortality. Aging Cell 9: 1057-1064, 2010.

8. Conte M, Martucci M, Chiariello A, Franceschi C and Salvioli S: Mitochondria, immunosenescence and inflammaging: A role for mitokines? Semin Immunopathol 42: 607-617, 2020.

9. Rochette L, Zeller M, Cottin Y and Vergely C: Insights into mechanisms of GDF15 and receptor GFRAL: Therapeutic targets. Trends Endocrinol Metab 31: 939-951, 2020.

10. Kang YE, Kim JM, Lim MA, Lee SE, Yi S, Kim JT, Oh C, Liu L, Jin Y, Jung SN, et al: Growth differentiation factor 15 is a cancer cell-induced mitokine that primes thyroid cancer cells for invasiveness. Thyroid 31: 772-786, 2021. 
11. Nakayasu ES, Syed F, Tersey SA, Gritsenko MA, Mitchell HD, Chan CY, Dirice E, Turatsinze JV, Cui Y, Kulkarni RN, et al: Comprehensive proteomics analysis of stressed human islets identifies GDF15 as a target for type 1 diabetes intervention. Cell Metab 31: 363-374.e6, 2020.

12. Wang Y, Zhen C, Wang R and Wang G: Growth-differentiation factor-15 predicts adverse cardiac events in patients with acute coronary syndrome: A meta-analysis. Am J Emerg Med 37: $1346-1352,2019$

13. Yang L, Chang CC, Sun Z, Madsen D, Zhu H, Padkjær SB, Wu X, Huang T, Hultman K, Paulsen SJ, et al: GFRAL is the receptor for GDF15 and is required for the anti-obesity effects of the ligand. Nat Med 23: 1158-1166, 2017.

14. Mullican SE, Lin-Schmidt $X$, Chin CN, Chavez JA, Furman JL, Armstrong AA, Beck SC, South VJ, Dinh TQ, Cash-Mason TD, et al: GFRAL is the receptor for GDF15 and the ligand promotes weight loss in mice and nonhuman primates. Nat Med 23: 1150-1157, 2017.

15. Hsu JY, Crawley S, Chen M, Ayupova DA, Lindhout DA, Higbee J, Kutach A, Joo W, Gao Z, Fu D, et al: Non-homeostatic body weight regulation through a brainstem-restricted receptor for GDF15. Nature 550: 255-259, 2017.

16. Emmerson PJ, Wang F, Du Y, Liu Q, Pickard RT, Gonciarz MD Coskun T, Hamang MJ, Sindelar DK, Ballman KK, et al: The metabolic effects of GDF15 are mediated by the orphan receptor GFRAL. Nat Med 23: 1215-1219, 2017.

17. Borner T, Shaulson ED, Ghidewon MY, Barnett AB, Horn CC, Doyle RP, Grill HJ, Hayes MR and De Jonghe BC: GDF15 induces anorexia through Nausea and Emesis. Cell Metab 31: 351-362.e5, 2020.

18. Klaus S, Igual Gil C and Ost M: Regulation of diurnal energy balance by mitokines. Cell Mol Life Sci 78: 3369-3384, 2021.

19. Kim DH, Lee D, Lim H, Choi SJ, Oh W, Yang YS, Chang JH and Jeon HB: Effect of growth differentiation factor- 15 secreted by human umbilical cord blood-derived mesenchymal stem cells on amyloid beta levels in in vitro and in vivo models of Alzheimer's disease. Biochem Biophys Res Commun 504: 933-940, 2018.

20. Kostuk EW, Cai J and Iacovitti L: Subregional differences in astrocytes underlie selective neurodegeneration or protection in Parkinson's disease models in culture. Glia 67: 1542-1557, 2019.

21. Breniere C, Meloux A, Pedard M, Marie C, Thouant P, Vergely C and Béjot Y: Growth differentiation factor-15 (GDF-15) is associated with mortality in ischemic stroke patients treated with acute revascularization therapy. Front Neurol 10: 611, 2019.

22. Li S, Wang Y, Cao B, Wu Y, Ji L, Li YX, Liu M, Zhao Y, Qiao J, Wang $\mathrm{H}$, et al: Maturation of growth differentiation factor 15 in human placental trophoblast cells depends on the interaction with Matrix Metalloproteinase-26. J Clin Endocrinol Metab 99: E2277-E2287, 2014

23. Couture F, Sabbagh R, Kwiatkowska A, Desjardins R, Guay SP, Bouchard L and Day R: PACE4 undergoes an oncogenic alternative splicing switch in cancer. Cancer Res 77: 6863-6879, 2017.

24. Fairlie WD, Russell PK, Wu WM, Moore AG, Zhang HP Brown PK, Bauskin AR and Breit SN: Epitope mapping of the transforming growth factor-beta superfamily protein, macrophage inhibitory cytokine-1 (MIC-1): Identification of at least five distinct epitope specificities. Biochemistry 40: 65-73, 2001.

25. Bauskin AR, Zhang HP, Fairlie WD, He XY, Russell PK, Moore AG, Brown DA, Stanley KK and Breit SN: The propeptide of macrophage inhibitory cytokine (MIC-1), a TGF-beta superfamily member, acts as a quality control determinant for correctly folded MIC-1. EMBO J 19: 2212-2220, 2000.

26. Bauskin AR, Jiang L, Luo XW, Wu L, Brown DA and Breit SN: The TGF-beta superfamily cytokine MIC-1/GDF15: secretory mechanisms facilitate creation of latent stromal stores. J Interferon Cytokine Res 30: 389-397, 2010.

27. Bauskin AR, Brown DA, Junankar S, Rasiah KK, Eggleton S, Hunter M, Liu T, Smith D, Kuffner T, Pankhurst GJ, et al: The propeptide mediates formation of stromal stores of PROMIC-1: Role in determining prostate cancer outcome. Cancer Res 65: 2330-2336, 2005.

28. Tsai VWW, Husaini Y, Sainsbury A, Brown DA and Breit SN: The MIC-1/GDF15-GFRAL pathway in energy homeostasis: Implications for obesity, cachexia, and other associated diseases. Cell Metab 28: 353-368, 2018.

29. Wollert KC, Kempf T and Wallentin L: Growth differentiation factor 15 as a biomarker in cardiovascular disease. Clin Chem 63 : 140-151, 2017.
30. Demir O, Barros EP, Offutt TL, Rosenfeld M and Amaro RE: An integrated view of p53 dynamics, function, and reactivation. Curr Opin Struct Biol 67: 187-194, 2021.

31. Tan M, Wang Y, Guan K and Sun Y: PTGF-beta, a type beta transforming growth factor (TGF-beta) superfamily member, is a p53 target gene that inhibits tumor cell growth via TGF-beta signaling pathway. Proc Natl Acad Sci USA 97: 109-114, 2000.

32. Kannan K, Amariglio N, Rechavi G and Givol D: Profile of gene expression regulated by induced p53: Connection to the TGF-beta family. FEBS Lett 470: 77-82, 2000.

33. Li PX, Wong J, Ayed A, Ngo D, Brade AM, Arrowsmith C, Austin RC and Klamut HJ: Placental transforming growth factor-beta is a downstream mediator of the growth arrest and apoptotic response of tumor cells to DNA damage and p53 overexpression. J Biol Chem 275: 20127-20135, 2000.

34. Yang H, Filipovic Z, Brown D, Breit SN and Vassilev LT: Macrophage inhibitory cytokine-1: A novel biomarker for p53 pathway activation. Mol Cancer Ther 2: 1023-1029, 2003.

35. Tiwari KK, Moorthy B and Lingappan K: Role of GDF15 (growth and differentiation factor 15) in pulmonary oxygen toxicity. Toxicol In Vitro 29: 1369-1376, 2015.

36. Kim Y, Noren Hooten $\mathrm{N}$ and Evans MK: CRP stimulates GDF15 expression in endothelial cells through p53. Mediators Inflamm 2018: 8278039, 2018.

37. Zhou Y, Zhong Y, Wang Y, Zhang X, Batista DL, Gejman R, Ansell PJ, Zhao J, Weng C and Klibanski A: Activation of p53 by MEG3 non-coding RNA. J Biol Chem 282: 24731-24742, 2007.

38. Osada M, Park HL, Park MJ, Liu JW, Wu G, Trink B and Sidransky D: A p53-type response element in the GDF15 promoter confers high specificity for $\mathrm{p} 53$ activation. Biochem Biophys Res Commun 354: 913-918, 2007.

39. Pagel JI and Deindl E: Disease progression mediated by egr-1 associated signaling in response to oxidative stress. Int J Mol Sci 13: 13104-13117, 2012

40. Baek SJ, Kim JS, Nixon JB, DiAugustine RP and Eling TE Expression of NAG-1, a transforming growth factor-beta superfamily member, by troglitazone requires the early growth response gene EGR-1. J Biol Chem 279: 6883-6892, 2004

41. Baek SJ, Kim JS, Moore SM, Lee SH, Martinez J and Eling TE: Cyclooxygenase inhibitors induce the expression of the tumor suppressor gene EGR-1, which results in the upregulation of NAG-1, an antitumorigenic protein. Mol Pharmacol 67: 356-364, 2005.

42. Chintharlapalli S, Papineni S, Baek SJ, Liu S and Safe S: 1,1-Bis(3'-indolyl)-1-(p-substitutedphenyl)methanes are peroxisome proliferator-activated receptor gamma agonists but decrease HCT-116 colon cancer cell survival through receptor-independent activation of early growth response- 1 and nonsteroidal anti-inflammatory drug-activated gene-1. Mol Pharmacol 68: 1782-1792, 2005.

43. Kadowaki M, Yoshioka H, Kamitani H, Watanabe T, Wade PA and Eling TE: DNA methylation-mediated silencing of nonsteroidal anti-inflammatory drug-activated gene (NAG-1/GDF15) in glioma cell lines. Int J Cancer 130: 267-277, 2012.

44. Woo SM, Min KJ, Kim S, Park JW, Kim DE, Chun KS, Kim YH, Lee TJ, Kim SH, Choi YH, et al: Silibinin induces apoptosis of HT29 colon carcinoma cells through early growth response-1 (EGR-1)-mediated non-steroidal anti-inflammatory drug-activated gene-1 (NAG-1) upregulation. Chem Biol Interact 211: 36-43, 2014.

45. Statello L, Guo CJ, Chen LL and Huarte M: Gene regulation by long non-coding RNAs and its biological functions. Nat Rev Mol Cell Biol 22: 96-118, 2021.

46. Kong J, Sun W, Zhu W, Liu C, Zhang H and Wang H: Long noncoding RNA LINC01133 inhibits oral squamous cell carcinoma metastasis through a feedback regulation loop with GDF15. J Surg Oncol 118: 1326-1334, 2018.

47. Xiong X, Yuan J, Zhang N, Zheng Y, Liu J and Yang M: Silencing of lncRNA PVT1 by miR-214 inhibits the oncogenic GDF15 signaling and suppresses hepatocarcinogenesis. Biochem Biophys Res Commun 521: 478-484, 2020.

48. Guo LL and Wang SF: Downregulated long noncoding RNA GAS5 fails to function as decoy of CEBPB, resulting in increased GDF15 expression and rapid ovarian cancer cell proliferation. Cancer Biother Radiopharm 34: 537-546, 2019.

49. Liu B, Li J and Cairns MJ: Identifying miRNAs, targets and functions. Brief Bioinform 15: 1-19, 2014.

50. Teng MS, Hsu LA, Juan SH, Lin WC, Lee MC, Su CW, Wu S and Ko YL: A GDF15 3' UTR variant, rs1054564, results in allele-specific translational repression of GDF15 by hsa-miR-1233-3p. PLoS One 12: e0183187, 2017. 
51. Jones MF, Li XL, Subramanian M, Shabalina SA, Hara T, Zhu Y, Huang J, Yang Y, Wakefield LM, Prasanth KV and Lal A: Growth differentiation factor-15 encodes a novel microRNA 3189 that functions as a potent regulator of cell death. Cell Death Differ 22: 1641-1653, 2015

52. Coll AP, Chen M, Taskar P, Rimmington D, Patel S, Tadross JA, Cimino I, Yang M, Welsh P, Virtue S, et al: GDF15 mediates the effects of metformin on body weight and energy balance. Nature 578: 444-448, 2020.

53. Melvin A, Chantzichristos D, Kyle CJ, Mackenzie SD, Walker BR, Johannsson G, Stimson RH and O'Rahilly S: GDF15 is elevated in conditions of glucocorticoid deficiency and is modulated by glucocorticoid replacement. J Clin Endocrinol Metab 105: $1427-1434,2020$

54. Campderros L, Moure R, Cairo M, Gavaldà-Navarro A, Quesada-López T, Cereijo R, Giralt M, Villarroya J and Villarroya F: Brown Adipocytes Secrete GDF15 in response to thermogenic activation. Obesity (Silver Spring) 27: 1606-1616, 2019.

55. Zhao J, Li M, Chen Y, Zhang S, Ying H, Song Z, Lu Y, Li X, Xiong $X$ and Jiang $\mathrm{J}$ : Elevated serum growth differentiation Factor 15 levels in hyperthyroid patients. Front Endocrinol (Lausanne) 9: 793, 2019.

56. Liu H, Dai W, Cui Y, Lyu Y and Li Y: Potential associations of circulating growth differentiation factor-15 with sex hormones in male patients with coronary artery disease. Biomed Pharmacother 114: 108792, 2019.

57. Ha G, De Torres F, Arouche N, Benzoubir N, Ferratge S, Hatem E, Anginot A and Uzan G: GDF15 secreted by senescent endothelial cells improves vascular progenitor cell functions. PLoS One 14: e0216602, 2019.

58. Jin YJ, Lee JH, Kim YM, Oh GT and Lee H: Macrophage inhibitory cytokine-1 stimulates proliferation of human umbilical vein endothelial cells by up-regulating cyclins D1 and E through the PI3K/Akt-, ERK-, and JNK-dependent AP-1 and E2F activation signaling pathways. Cell Signal 24: 1485-1495, 2012.

59. Song H, Yin D and Liu Z: GDF-15 promotes angiogenesis through modulating $\mathrm{p} 53 / \mathrm{HIF}-1 \alpha$ signaling pathway in hypoxic human umbilical vein endothelial cells. Mol Biol Rep 39: 4017-4022, 2012.

60. Wang S, Li M, Zhang W, Hua H, Wang N, Zhao J, Ge J, Jiang X, Zhang Z, Ye D and Yang C: Growth differentiation factor 15 promotes blood vessel growth by stimulating cell cycle progression in repair of critical-sized calvarial defect. Sci Rep 7: 9027, 2017.

61. Lugano R, Ramachandran M and Dimberg A: Tumor angiogenesis: causes, consequences, challenges and opportunities. Cell Mol Life Sci 77: 1745-1770, 2020.

62. Dong G, Zheng QD, Ma M, Wu SF, Zhang R, Yao RR, Dong YY, Ma H, Gao DM, Ye SL, et al: Angiogenesis enhanced by treatment damage to hepatocellular carcinoma through the release of GDF15. Cancer Med 7: 820-830, 2018.

63. Whitson RJ, Lucia MS and Lambert JR: Growth differentiation factor-15 (GDF-15) suppresses in vitro angiogenesis through a novel interaction with connective tissue growth factor (CCN2). J Cell Biochem 114: 1424-1433, 2013.

64. Kist M and Vucic D: Cell death pathways: Intricate connections and disease implications. EMBO J 40: e106700, 2021.

65. Zhu S, Yang N, Guan Y, Wang X, Zang G, Lv X, Deng S, Wang W, $\mathrm{Li} \mathrm{T}$ and Chen J: GDF15 promotes glioma stem cell-like phenotype via regulation of ERK1/2-c-Fos-LIF signaling. Cell Death Discov 7: 3, 2021.

66. Zhang W, Hu C, Wang X, Bai S, Cao S, Kobelski M, Lambert JR, $\mathrm{Gu} \mathrm{J}$ and Zhan Y: Role of GDF15 in methylseleninic acidmediated inhibition of cell proliferation and induction of apoptosis in prostate cancer cells. PLoS One 14: e0222812, 2019.

67. Liu T, Bauskin AR, Zaunders J, Brown DA, Pankhurst S, Russell PJ and Breit SN: Macrophage inhibitory cytokine 1 reduces cell adhesion and induces apoptosis in prostate cancer cells. Cancer Res 63: 5034-5040, 2003.

68. Schlittenhardt D, Schober A, Strelau J, Bonaterra GA, Schmiedt W, Unsicker K, Metz J and Kinscherf R: Involvement of growth differentiation factor-15/macrophage inhibitory cytokine-1 (GDF-15/MIC-1) in oxLDL-induced apoptosis of human macrophages in vitro and in arteriosclerotic lesions. Cell Tissue Res 318: 325-333, 2004

69. Tarfiei GA, Shadboorestan A, Montazeri H, Rahmanian N, Tavosi $\mathrm{G}$ and Ghahremani MH: GDF15 induced apoptosis and cytotoxicity in A549 cells depends on TGFBR2 expression. Cell Biochem Funct 37: 320-330, 2019.
70. Li J, Yang L, Qin W, Zhang G, Yuan J and Wang F: Adaptive induction of growth differentiation factor 15 attenuates endothelial cell apoptosis in response to high glucose stimulus. PLoS One 8: e65549, 2013

71. Nickel N, Jonigk D, Kempf T, Bockmeyer CL, Maegel L, Rische J, Laenger F, Lehmann U, Sauer C, Greer M, et al: GDF-15 is abundantly expressed in plexiform lesions in patients with pulmonary arterial hypertension and affects proliferation and apoptosis of pulmonary endothelial cells. Respir Res 12: 62, 2011.

72. Suriben R, Chen M, Higbee J, Oeffinger J, Ventura R, Li B Mondal K, Gao Z, Ayupova D, Taskar P, et al: Antibody-mediated inhibition of GDF15-GFRAL activity reverses cancer cachexia in mice. Nat Med 26: 1264-1270, 2020.

73. Chrysovergis K, Wang X, Kosak J, Lee SH, Kim JS, Foley JF, Travlos G, Singh S, Baek SJ and Eling TE: NAG-1/GDF-15 prevents obesity by increasing thermogenesis, lipolysis and oxidative metabolism. Int J Obes (Lond) 38: 1555-1564, 2014

74. Tsai VW, Zhang HP, Manandhar R, Schofield P, Christ D, Lee-Ng KKM, Lebhar H, Marquis CP, Husaini Y, Brown DA and Breit SN: GDF15 mediates adiposity resistance through actions on GFRAL neurons in the hindbrain AP/NTS. Int J Obes (Lond) 43: 2370-2380, 2019.

75. Zhang Z, Xu X, Tian W, Jiang R, Lu Y, Sun Q, Fu R, He Q, Wang J, Liu Y, et al: ARRB1 inhibits non-alcoholic steatohepatitis progression by promoting GDF15 maturation. J Hepatol 72: 976-989, 2020

76. Zhang M, Sun W, Qian J and Tang Y: Fasting exacerbates hepatic growth differentiation factor 15 to promote fatty acid $\beta$-oxidation and ketogenesis via activating XBP1 signaling in liver. Redox Biol 16: 87-96, 2018.

77. Luan HH, Wang A, Hilliard BK, Carvalho F, Rosen CE, Ahasic AM, Herzog EL, Kang I, Pisani MA, Yu S, et al: GDF15 is an inflammation-induced central mediator of tissue tolerance. Cell 178: 1231-1244.e11, 2019.

78. Wu Q, Jiang D, Schaefer NR, Harmacek L, O'Connor BP Eling TE, Eickelberg O and Chu HW: Overproduction of growth differentiation factor 15 promotes human rhinovirus infection and virus-induced inflammation in the lung. Am J Physiol Lung Cell Mol Physiol 314: L514-L527, 2018.

79. Abulizi P, Loganathan N, Zhao D, Mele T, Zhang Y, Zwiep T, Liu $\mathrm{K}$ and Zheng $\mathrm{X}$ : Growth differentiation factor-15 deficiency augments inflammatory response and exacerbates septic heart and renal injury induced by lipopolysaccharide. Sci Rep 7: 1037, 2017.

80. Li A, Zhao F, Zhao Y, Liu H and Wang Z: ATF4-mediated GDF15 suppresses LPS-induced inflammation and MUC5AC in human nasal epithelial cells through the PI3K/Akt pathway. Life Sci 275: 119356, 2021.

81. Li M, Song K, Huang X, Fu S and Zeng Q: GDF15 prevents LPS and D-galactosamine-induced inflammation and acute liver injury in mice. Int J Mol Med 42: 1756-1764, 2018.

82. Hu X, Wang T and Jin F: Alzheimer's disease and gut microbiota. Sci China Life Sci 59: 1006-1023, 2016.

83. Chen YG: Research progress in the pathogenesis of Alzheimer's disease. Chin Med J (Engl) 131: 1618-1624, 2018.

84. Strelau J, Sullivan A, Bottner M, Lingor P, Falkenstein E, Suter-Crazzolara C, Galter D, Jaszai J, Krieglstein K and Unsicker K: Growth/differentiation factor-15/macrophage inhibitory cytokine-1 is a novel trophic factor for midbrain dopaminergic neurons in vivo. J Neurosci 20: 8597-8603, 2000.

85. Schober A, Bottner M, Strelau J, Kinscherf R, Bonaterra GA, Barth M, Schilling L, Fairlie WD, Breit SN and Unsicker K: Expression of growth differentiation factor-15/macrophage inhibitory cytokine-1 (GDF-15/MIC-1) in the perinatal, adult, and injured rat brain. J Comp Neurol 439: 32-45, 2001.

86. Fuchs T, Trollor JN, Crawford J, Brown DA, Baune BT, Samaras K, Campbell L, Breit SN, Brodaty H, Sachdev P and Smith E: Macrophage inhibitory cytokine-1 is associated with cognitive impairment and predicts cognitive decline-the Sydney memory and aging study. Aging Cell 12: 882-889, 2013

87. Chai YL, Hilal S, Chong JPC, Ng YX, Liew OW, Xu X, Ikram MK, Venketasubramanian N, Richards AM, Lai MKP and Chen CP: Growth differentiation factor-15 and white matter hyperintensities in cognitive impairment and dementia. Medicine (Baltimore) 95: e4566, 2016.

88. Low JK, Ambikairajah A, Shang K, Brown DA, Tsai VW, Breit SN and Karl T: First behavioural characterisation of a knockout mouse model for the transforming growth factor (TGF)- $\beta$ superfamily cytokine, MIC-1/GDF15. PLoS One 12: e0168416, 2017. 
89. Nasrabady SE, Rizvi B, Goldman JE and Brickman AM: White matter changes in Alzheimer's disease: A focus on myelin and oligodendrocytes. Acta Neuropathol Commun 6: 22, 2018.

90. Jiang J, Trollor JN, Brown DA, Crawford JD, Thalamuthu A, Smith E, Breit SN, Liu T, Brodaty H, Baune BT, et al: An inverse relationship between serum macrophage inhibitory cytokine-1 levels and brain white matter integrity in community-dwelling older individuals. Psychoneuroendocrinology 62: 80-88, 2015.

91. Jiang J, Wen W, Brown DA, Crawford J, Thalamuthu A, Smith E, Breit SN, Liu T, Zhu W, Brodaty H, et al: The relationship of serum macrophage inhibitory cytokine-1 levels with gray matter volumes in community-dwelling older individuals. PLoS One 10: e0123399, 2015.

92. Mu Y and Gage FH: Adult hippocampal neurogenesis and its role in Alzheimer's disease. Mol Neurodegener 6: 85, 2011.

93. Strelau J, Strzelczyk A, Rusu P, Bendner G, Wiese S, Diella F, Altick AL, von Bartheld CS, Klein R, Sendtner M and Unsicker K: Progressive postnatal motoneuron loss in mice lacking GDF-15. J Neurosci 29: 13640-13648, 2009.

94. Carrillo-Garcia C, Prochnow S, Simeonova IK, Strelau J, Hölzl-Wenig G, Mandl C, Unsicker K, von Bohlen Und Halbach O and Ciccolini F: Growth/differentiation factor 15 promotes EGFR signalling, and regulates proliferation and migration in the hippocampus of neonatal and young adult mice. Development 141: 773-783, 2014.

95. Kim DH, Lee D, Chang EH, Kim JH, Hwang JW, Kim JY, Kyung JW, Kim SH, Oh JS, Shim SM, et al: GDF-15 secreted from human umbilical cord blood mesenchymal stem cells delivered through the cerebrospinal fluid promotes hippocampa neurogenesis and synaptic activity in an Alzheimer's disease model. Stem Cells Dev 24: 2378-2390, 2015.

96. Sudhof TC: Molecular neuroscience in the 21st Century: A personal perspective. Neuron 96: 536-541, 2017.

97. Liu DD, Lu JM, Zhao QR, Hu C and Mei YA: Growth differentiation factor- 15 promotes glutamate release in medial prefrontal cortex of mice through upregulation of T-type calcium channels Sci Rep 6: 28653, 2016

98. Ballard C, Gauthier S, Corbett A, Brayne C, Aarsland D and Jones E: Alzheimer's disease. Lancet 377: 1019-1031, 2011.

99. Tesseur I, Zou K, Esposito L, Bard F, Berber E, Can JV, Lin AH, Crews L, Tremblay P, Mathews P, et al: Deficiency in neuronal TGF-beta signaling promotes neurodegeneration and Alzheimer's pathology. J Clin Invest 116: 3060-3069, 2006.

100. Das P and Golde T: Dysfunction of TGF-beta signaling in Alzheimer's disease. J Clin Invest 116: 2855-2857, 2006.

101. Koh SH and Park HH: Neurogenesis in stroke recovery. Transl Stroke Res 8: 3-13, 2017.

102. Barthels D and Das H: Current advances in ischemic stroke research and therapies. Biochim Biophys Acta Mol Basis Dis 1866: 165260,2020

103. Xiang Y, Zhang T, Guo J, Peng YF and Wei YS: The association of growth differentiation factor- 15 gene polymorphisms with growth differentiation factor-15 serum levels and risk of ischemic stroke. J Stroke Cerebrovasc Dis 26: 2111-2119, 2017.

104. Brown DA, Breit SN, Buring J, Fairlie WD, Bauskin AR, Liu T and Ridker PM: Concentration in plasma of macrophage inhibitory cytokine- 1 and risk of cardiovascular events in women: A nested case-control study. Lancet 359: 2159-2163, 2002.

105. Worthmann H, Kempf T, Widera C, Tryc AB, Goldbecker A, Ma YT, Deb M, Tountopoulou A, Lambrecht J, Heeren M, et al: Growth differentiation factor 15 plasma levels and outcome after ischemic stroke. Cerebrovasc Dis 32: 72-78, 2011.

106. Yin J, Zhu Z, Guo D, Wang A, Zeng N, Zheng X, Peng Y, Zhong C, Wang G, Zhou Y, et al: Increased growth differentiation factor 15 is associated with unfavorable clinical outcomes of acute ischemic stroke. Clin Chem 65: 569-578, 2019.
107. Groschel K, Schnaudigel S, Edelmann F, Niehaus CF, Weber-Krüger M, Haase B, Lahno R, Seegers J, Wasser K, Wohlfahrt J, et al: Growth-differentiation factor-15 and functional outcome after acute ischemic stroke. J Neurol 259: 1574-1579, 2012.

108. Dong X and Nao J: Association of serum growth differentiation factor 15 level with acute ischemic stroke in a Chinese population. Int J Neurosci 129: 1247-1255, 2019.

109. Wang X, Zhu L, Wu Y, Sun K, Su M, Yu L, Chen J, Li W, Yang J, Yuan Z and Hui R: Plasma growth differentiation factor 15 predicts first-ever stroke in hypertensive patients. Medicine (Baltimore) 95: e4342, 2016.

110. Schindowski K, von Bohlen und Halbach O, Strelau J, Ridder DA, Herrmann O, Schober A, Schwaninger M and Unsicker K: Regulation of GDF-15, a distant TGF- $\beta$ superfamily member, in a mouse model of cerebral ischemia. Cell Tissue Res 343: 399-409, 2011.

111. Dickson DW: Neuropathology of Parkinson disease. Parkinsonism Relat Disord 46 (Suppl 1): S30-S33, 2018.

112. Obeso JA, Rodriguez-Oroz MC, Goetz CG, Marin C Kordower JH, Rodriguez M, Hirsch EC, Farrer M, Schapira AH and Halliday G: Missing pieces in the Parkinson's disease puzzle. Nat Med 16: 653-661, 2010

113. Maetzler W, Deleersnijder W, Hanssens V, Bernard A, Brockmann K, Marquetand J, Wurster I, Rattay TW, Roncoroni L, Schaeffer E, et al: GDF15/MIC1 and MMP9 cerebrospinal fluid levels in Parkinson's disease and lewy body dementia. PLoS One 11: e0149349, 2016.

114. Movement Disorder Society Task Force on Rating Scales for Parkinson's Disease: The unified Parkinson's disease rating scale (UPDRS): Status and recommendations. Mov Disord 18: 738-750, 2003

115. Yao X, Wang D, Zhang L, Wang L, Zhao Z, Chen S, Wang X, Yue T and Liu Y: Serum growth differentiation factor 15 in Parkinson disease. Neurodegener Dis 17: 251-260, 2017.

116. Luthman J, Fredriksson A, Sundstrom E, Jonsson G and Archer T: Selective lesion of central dopamine or noradrenaline neuron systems in the neonatal rat: Motor behavior and monoamine alterations at adult stage. Behav Brain Res 33: 267-277, 1989.

117. Machado V, Haas SJ, von Bohlen Und Halbach O, Wree A, Krieglstein K, Unsicker K and Spittau B: Growth/differentiation factor-15 deficiency compromises dopaminergic neuron survival and microglial response in the 6-hydroxydopamine mouse model of Parkinson's disease. Neurobiol Dis 88: 1-15, 2016

118. Machado V, Gilsbach R, Das R, Schober A, Bogatyreva L, Hauschke D, Krieglstein K, Unsicker K and Spittau B: Gdf-15 deficiency does not alter vulnerability of nigrostriatal dopaminergic system in MPTP-intoxicated mice. Cell Tissue Res 365: 209-223, 2016

119. Hirsch E, Graybiel AM and Agid YA: Melanized dopaminergic neurons are differentially susceptible to degeneration in Parkinson's disease. Nature 334: 345-348, 1988.

120. Liu H, Liu J, Si L, Guo C, Liu W and Liu Y: GDF-15 promotes mitochondrial function and proliferation in neuronal HT22 cells. J Cell Biochem 120: 10530-10547, 2019.

121. Miyaue N, Yabe H and Nagai M: Serum growth differentiation factor 15, but not lactate, is elevated in patients with Parkinson's disease. J Neurol Sci 409: 116616, 2020.

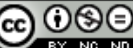

This work is licensed under a Creative Commons Attribution-NonCommercial-NoDerivatives 4.0 International (CC BY-NC-ND 4.0) License. 